\title{
KOMUNIKASI PENDIDIKAN \\ (Urgensi Komunikasi Efektif dalam Proses Pembelajaran)
}

\author{
Ujang Mahadi \\ STAI Ibnu Rusyd Kotabumi Lampung Utara \\ mahadi4kdzhnh@yahoo.com
}

\begin{abstract}
ABSTRAK
Penelitian ini bertujuan untuk mengetahui efektivitas komunikasi pendidikan di dalam proses pembelajaran. Penelitian ini menggunakan pendekatan kuantitatif, dengan metode penelitian explanatory research. Hasil penelitian bahwa komunikasi menjadi bagian penting, kebutuhan dasar dan media untuk berinteraksi dengan sesama untuk menyampaikan perasaan, pendapat, pikiran, informasi, nasihat dan berbagi pengalaman kepada orang lain. Komunikasi efektif juga menjadi bagian penting dalam komunikasi pendidikan untuk menyampaikan pesan edukatif dalam proses pembelajaran. Komunikasi pendidikan dikatakan efektif jika materi pelajaran yang disampaikan tenaga pendidik dapat diterima dan dipahami dengan baik serta menimbulkan umpan balik yang positif oleh peserta didik. Simpulan penelitian Ini bahwa itu tenaga pendidik perlu mempelajari ilmu komunikasi, komponen, fungsi dan tujuan komunikasi, komunikasi efektif, komunikasi antar budaya, dan konsep dasar komunikasi pendidikan. Karena keberhasilan pendidikan banyak ditentukan oleh kemampuan dan keterampilan tenaga pendidik dalam berkomunikasi yang efektif.
\end{abstract}

Kata Kunci: Komunikasi, Komunikasi Efektif, Komunikasi Pendidikan.

\section{ABSTRACT}

This study aims to determine the effectiveness of educational communication in the learning process. This study uses a quantitative approach, with explanatory research methods. The results of the study show that communication is an important part, a basic need and a medium for interacting with others to convey feelings, opinions, thoughts, information, advice and share experiences with others. Effective communication is also an important part of educational communication to convey educational messages in the learning process. Educational communication is said to be effective if the subject matter delivered by educators can be well received and understood and generates positive feedback by students. The conclusion of this research is that educators need to learn "communication science", components, functions and objectives of communication, effective communication, intercultural communication, and the basic concepts of educational communication. Because the success of education is largely determined by the ability and skills of educators in effective communication.

Keywords: Communication, Effective Communication, Educational Communication. 


\section{PENDAHULUAN}

Komunikasi merupakan bagian penting dan tidak dapat dipisahkan dari aktivitas kehidupan manusia, baik sebagai individu maupun sebagai makhluk sosial. Dalam hubungan sosial, komunikasi sebagai media untuk berinteraksi dengan sesama, berbagi informasi, menyampaikan keinginan, perasaan, pikiran, informasi,pendapat, dan nasihat,serta pengalamannya kepada orang lain. Tidak ada manusia yang tidak melakukan komunikasi dalam memenuhi hajat hidupnya, baik secara langsung bertatap muka, maupun tidak langsung dengan menggunakan perangkat media tertentu, baikitu media cetak maupun media elektronik. Artinya, bahwa komunikasi menjadi urat nadi dan sistem hidup manusia sebagai makhluk sosial.

Manusia dari bangun tidur di pagi hari hingga berbaring kembali menjelang tengah malam, $70 \%$ waktu bangun, digunakan untuk berkomunikasi. Ini berarti, kualitas hidup kita banyak ditentukan oleh bagaimana kita berkomunikasi dengan sesama (Adhim, 2005). Setiap orang yang hidup dalam masyarakat, sejak bangun tidur sampai tidur lagi, secara kodrati senantiasa terlibat dalam komunikasi. Terjadinya komunikasi adalah sebagai konsekuensi hubungan sosial "social relations" (Effendy, 2000).

Dalam aktivitas pendidikan,komunikasi juga mempunyai peran yang sangat penting dan strategis dalam membangun interaksi dan menyampaikan pesan edukatif, berupa materi belajar dari pendidik kepada peserta didik agar materi belajar dapat diterima dan dicerna dengan baik,dapat berpengaruh terhadap pemahaman dan perubahan tingkah laku peserta didik.

Keberhasilan mewujudkan tujuan pendidikan sangat tergantung kepada efektivitas proses komunikasi pendidikan yang berlangsung di sekolah antara pendidik dengan peserta didik dalam kegiatan pembelajaran.Untuk menciptakan komunikasi yang efektif dalam proses pembelajaran, tenaga pendidik harus memahami konsep dasar ilmu komunikasi, tujuan dan fungsi komunikasi, komponen komunikasi, komunikasi efektif, dan tidak kalah pentingnya adalah komunikasi pendidikan.

\section{METODE PENELITIAN}

Penelitian ini menggunakan metode kuantitatif, aplikasi rumus statistik untuk membantu menganalisis data dan fakta yang diperoleh di lapangan, rancangan penelitian menggunakan metode explanatory research.

\section{HASIL DAN PEMBAHASAN \\ Hakikat Manusia dan Pendidikan}

Manusia adalah makhluk multidimensional yang dapat ditelaah dari berbagai sudut pandang. Spranger (1950)sebagaimana dikutip Riyanto, melihat manusia sebagai makhluk jasmani dan rohani. Adapun yang membedakan manusia dengan makhluk lain adalah aspek kerohanian. Manusia akan menjadi sungguh-sungguh manusia kalau ia mengembangkan nilai-nilai rohani (nilai-nilai budaya), yang meliputi: nilai pengetahuan, keagamaan, kesenian, ekonomi, kemasyarakatan dan politik.

Manusia adalah makhluk ciptaan Tuhan yang dibekali dengan akal dan pikiran. Manusia merupakan ciptaan Tuhan Yang Maha Esa yang memiliki derajat paling tinggi di antara ciptaannya yang lain. Hal yang paling penting 
dalam membedakan manusia dengan makhluk lainnya adalah bahwa manusia dilengkapi dengan akal, pikiran, perasaan, dan keyakinan untuk mempertinggi kualitas hidupnya di dunia (Sumantri, 2019).

Heryanto (2008) menjelaskan tentang hakikat manusia adalah sebagai berikut: (1). Manusia sebagai makhluk Tuhan mempunyai kebutuhan bertaqwa kepada Tuhan Yang Maha Esa. (2). Manusia membutuhkan lingkungan hidup berkelompok untuk mengembangkan dirinya. (3). Manusia mempunyai potensipotensi yang dapat dikembangkan dan kebutuhan-kebutuhan materi serta spiritual yang harus dipenuhi. (4). Manusia itu pada dasarnya dapat dan harus dididik serta dapat mendidik diri sendiri.

Howard Gardner (1983) dalam Theo Riyanto menelaah manusia dari sudut kehidupan mentalnya, khususnya aktivitas inteligensia (kecerdasan). Menurut dia, paling tidak manusia memiliki 7 macam kecerdasan yaitu: (1). Kecerdasan matematis/logis: yaitu kemampuan penalaran ilmiah, penalaran induktif/deduktif, berhitung/angka dan pola-pola abstrak. (2). Kecerdasan verbal/bahasa: yaitu kemampuan yang berhubungan dengan kata/bahasa tertulis maupun lisan (sebagian materi pelajaran di sekolah berhubungan dengan kecerdasan ini). (3) Kecerdasan interpersonal: yaitu kemampuan yang berhubungan dengan keterampilan berelasi dengan orang lain, berkomunikasi antar pribadi. (4). Kecerdasan fisik/gerak/badan: yaitu kemampuan mengatur gerakan badan, memahami sesuatu berdasar gerakan. (5). Kecerdasan musikal/ritme: yaitu kemampuan penalaran berdasarkan pola nada atau ritme. Kepekaan akan suatu nada atau ritme. (6). Kecerdasan visual/ruang/spasial: yaitu kemampuan yang mengandalkan penglihatan dan kemampuan membayangkan objek. Kemampuan menciptakan gambaran mental. (7). Kecerdasan intrapersonal: yaitu kemampuan yang berhubungan dengan kesadaran kebatinan seperti refleksi diri, kesadaran akan hal-hal rohani.

Manusia adalah kesatuan badani-rohani, hidup dalam ruang dan waktu, sadar akan diri dan lingkungannya, mempunyai berbagai kebutuhan, insting, nafsu, dan tujuan hidup. Manusia memiliki berbagai potensi, yaitu potensi untuk mampu beriman dan bertakwa kepada Tuhan Yang Maha Esa, berbuat baik, cipta, rasa, karsa, dan karya. Dalam eksistensinya, manusia memiliki berbagai aspek kehidupan individualitas, sosialitas, kultural, moralitas, dan religius. Semua itu, mengimplikasikan interaksi atau komunikasi, historisitas, dan dinamika (Sumantri, 2019).

Dari pemaparan di atas dapat dipahami bahwa manusia itu adalah makhluk yang paling sempurna, baik dari aspek fisik, jasmaniah maupun mental, rohaniah. Manusia tidak saja dibekali akal pikiran namun juga dibekali hawa nafsu, sehingga manusia punya berbagai keinginan dalam hidupnya, termasuk keinginan untuk mempertinggi kualitas hidupnya melalui pendidikan. Manusia mempunyai kecerdasan dan memiliki berbagai potensi yang dapat dikembangkan untuk membangun peradaban yang lebih baik, lebih maju, dan lebih beradab.

\section{Hakikat Pendidikan}

Pendidikan merupakan usaha sadar dan terencana untuk mewujudkan suasana belajar dan proses pembelajaran agar peserta didik secara aktif mengembangkan potensi dirinya untuk memiliki kekuatan keagamaan, pengendalian diri, kepribadian, kecerdasan, akhlak mulia, serta keterampilan yang 
diperlukan dirinya, masyarakat, bangsa, dan negara (Burhanuddin, 2014).Makna pendidikan secara sederhana dapat diartikan sebagai usaha manusia untuk membina kepribadiannya sesuai dengan nilai-nilai yang ada di dalam masyarakat dan kebudayaannya (Saefuddin, 2019).

Pendidikan adalah proses mengubah sikap dan perilaku seseorang atau kelompok orang dalam usaha mendewasakan manusia melalui pengajaran dan pelatihan. Jadi dalam hal ini pendidikan adalah proses atau perbuatan mendidik. Pendapat lain mengatakan bahwa pendidikan adalah bimbingan atau pertolongan yang diberikan oleh orang dewasa kepada perkembangan anak untuk mencapai kedewasaannya dengan tujuan agar anak cukup cakap dalam melaksanakan tugas hidupnya sendiri tidak dengan bantuan orang lain (Sumantri, 2019).

Heryanto (2008), menjelaskan tentang hakikat pendidikan adalah sebagai berikut: a). Pendidikan merupakan proses interaksi manusiawi yang ditandai keseimbangan antara kedaulatan subjek didik dengan kewibawaan pendidik. b). Pendidikan merupakan usaha penyiapan subjek didik menghadapi lingkungan yang mengalami perubahan yang semakin pesat. c). Pendidikan meningkatkan kualitas kehidupan pribadi dan masyarakat. d). Pendidikan berlangsung seumur hidup. e). Pendidikan merupakan kiat dalam menerapkan prinsip-prinsip ilmu pengetahuan dan teknologi bagi pembentukan manusia seutuhnya.

Pendidikan yang benar adalah suatu usaha pembinaan pribadi manusia untuk mencapai tujuan akhirnya (perilaku hubungan dengan Tuhan dan diri sendiri) dan sekaligus untuk kepentingan masyarakat (perilaku hubungan dengan diri sendiri, keluarga, masyarakat dan alam sekitarnya) (Riyanto, 2007).

Pendidikan merupakan proses memanusiakan manusia baik dalam bentuk formal maupun informal. Pendidikan dalam bentuk formal adalah pengajaran, yakni proses transfer pengetahuan atau usaha mengembangkan dan mengeluarkan potensi intelektualitas dari dalam diri manusia. Pendidikan bukan hanya sekedar transfer of knowledge atau peralihan ilmu pengetahuan semata, akan tetapi dengan adanya pendidikan diharapkan peserta didik mampu mengetahui dan memahami eksistensi dan potensi yang mereka miliki (Sumantri, 2019).

Penulis berpendapat bahwa pendidikan merupakan usaha sadar yang dilakukan tenaga pendidik dalam usaha pembinaan kepribadian peserta didik, mengembangkan potensi intelektualitas dan keterampilan, menumbuhkan kesadaran akan pentingnya pengendalian diri dan akhlakul karimah. Artinya, bahwa pendidikan itu tidak hanya sekadar transfer of knowledge semata, melainkan juga upaya agar peserta didik mampu menggali potensi dirinya dan dapat memahami eksistensi dirinya.

\section{Pengertian Komunikasi}

Komunikasi adalah proses penyampaian informasi-informasi, pesan-pesan, gagasan-gagasan atau pengertian-pengertian, dengan menggunakan lambanglambang yang mengandung arti atau makna, baik secara verbal maupun nonverbal dari seseorang atau sekelompok orang kepada seseorang atau sekelompok orang lainnya dengan tujuan untuk mencapai saling pengertian dan/atau kesepakatan bersama (Rudy, 2005). Komunikasi adalah proses penyampaian suatu pesan oleh seseorang kepada orang lain untuk memberi tahu atau untuk mengubah sikap, pendapat, atau perilaku, baik langsung secara lisan maupun tak langsung melalui media (Effendy, 2004). 
Definisi komunikasi adalah proses penyampaian dan penerimaan informasi-informasi, pesan-pesan, gagasan-gagasan atau pengertian-pengertian, dengan menggunakan lambang-lambang yang mengandung arti atau makna, baik secara verbal maupun non-verbal dari seseorang atau sekelompok orang kepada seseorang atau sekelompok orang lainnya dengan tujuan untuk mencapai saling pengertian dan/atau kesepakatan bersama, mengubah sikap/perilaku/pendapat, baik langsung secara lisan maupun tidak langsung melalui media.

\section{Komunikasi Pendidikan}

Komunikasi pendidikan adalah aspek komunikasi dalam dunia pendidikan (interaksi edukatif), atau komunikasi yang terjadi pada bidang-bidang pendidikan. Jadi segala interaksi yang terhubung dalam semua aspek pendidikan yang saling berkaitan dan saling mendukung satu sama lainnya dapat dikatakan sebagai "komunikasi pendidikan". Hal ini selaras dengan konsep pendidikan yang dikemukakan oleh Ki Hajar Dewantara yaitu: Ing ngarso sung tulodho, di depan memberi keteladanan/contoh yang baik; Ing madya mangun karso, di tengah membangkitkan keinginan/semangat; Tut wuri handayani, di belakang memberi motivasi/dukungan.Ketiga unsur tersebut menjadi spirit dan terbangun dalam kesatuan yang utuh pada aktivitas pendidikan.

Komunikasi pendidikan dapat memberikan kontribusi yang sangat signifikan dalam memberikan penjelasan dan pemahaman atas materi pembelajaran yang diberikan kepada peserta didik. Bahkan interaksi yang dibangun dalam proses pembelajaran akan lebih dinamis dengan melibatkan semua individu yang terlibat di dalamnya. Komunikasi dalam pendidikan sangat besar peranannya dalam menentukan keberhasilan dan tujuan yang akan dicapai dalam pendidikan.

Interaksi manusia dalam pendidikan tidak hanya timbal balik dalam arti komunikasi dua arah melainkan harus lebih tinggi mencapai tingkat manusiawi seperti saya atau siswa mendidik diri sendiri atas dasar hubungan pribadi dengan pribadi (higher order interactions) antar individu dan hubungan intrapersonal secara afektif antara saya (yaitu I) dan diriku (diri sendiri yaitu my self atau the self)(Heryanto, 2008).

Harus disadari bahwa komunikasi dalam pendidikan merupakan elemen dasar yang sangat penting kedudukan dan peranannya dalam mewujudkan keberhasilan proses pendidikan yang dijalankan.Komunikasi dalam pendidikan dapat mempengaruhi pencapaian mutu pendidikan. Proses belajar mengajar tidak bisa dilepaskan dari komunikasi pendidikan, oleh karena itu, penting bagi tenaga pendidik untuk terampil berkomunikasi serta memahami ilmu dan prinsip-prinsip komunikasi efektif dalam pendidikan.

\section{Komponen/Unsur Komunikasi Pembelajaran}

Agar proses komunikasi dalam pembelajaran bisa berlangsung sebagaimana mestinya,terdapat beberapa komponen atau unsur komunikasi, yaitu:

Komunikator merupakan pihak yang mengirimkan pesan dalam proses komunikasi. Komunikator dalam proses pembelajaran adalah tenaga pendidik, bisa guru atau dosen. Komunikator tidak hanya berperan sebagai penyampai pesan saja dalam proses pembelajaran, akan tetapi dapat memberikan 
respon/tanggapan atau menjawab berbagai pertanyaan yang diajukan oleh peserta didik.

Pesan atau informasi merupakan materi yang disampaikan oleh komunikator dalam proses pembelajaran. Pesan bisa berupa bahan ajar atau tugas yang diberikan tenaga pendidik kepada peserta didik.

Sarana komunikasi atau channel adalah media yang digunakan sebagai penyalur pesan dalam proses komunikasi pendidikan, bisa berupa LCD atau media lainnya, tentu saja media yang digunakan menyesuaikan dengan bahan ajar yang disampaikan.

Komunikan adalah orang yang menerima pesan atau berita, dalam proses pembelajaran yang menjadi komunikan adalah peserta didik, bisa murid atau mahasiswa.

Umpan balik bisa diartikan sebagai respon komunikan atas pesan yang disampaikan komunikator. Dalam proses pembelajaran respon bisa berupa pertanyaan, sanggahan atau hal lain yang disampaikan peserta didik kepada tenaga pendidik.

Dampak adalah efek dari pesan yang disampaikan komunikator kepada komunikan. Jika komunikan ada perubahan setelah menerima pesan maka komunikatordapat dikatakan berhasil dalam menyampaikan pesan sesuai tujuan yang diharapkan.

Menurut Sanaky (2019) komponen yang terdapat dalam komunikasi pembelajaran adalah sebagai berikut: 1). Pengajar dapat menjalankan fungsinya sebagai pemberi pesan (komunikator). 2). Pembelajar sebagai penerima pesan (komunikan). 3). Materi pelajaran sebagai pesan. 4). Alat bantu pembelajaran sebagai saluran atau media pembelajaran. 5). Faktor lain dalam pembelajaran adalah umpan balik yang manifestasinya berupa pertanyaan, jawaban, dan persilangan pendapat, baik dari pembelajar maupun dari pengajar.

\section{Komunikasi Efektif.}

Komunikasi efektif adalah komunikasi yang mampu untuk menghasilkan perubahan sikap pada orang yang terlihat dalam komunikasi. Tujuan komunikasi efektif adalah memberi kemudahan dalam memahami pesan yang disampaikan antara pemberi dan penerima sehingga bahasa lebih jelas, lengkap, pengiriman dan umpan balik seimbang, dan melatih menggunakan bahasa non verbal secara baik (Suprapto, 2017).

Menurut Larson dan Knapp (2016) komunikasi yang efektif dapat dicapai dengan mengusahakan ketepatan (accuracy) yang paling tinggi derajatnya antara komunikator dan komunikan dalam proses komunikasi. Komunikasi yang efektif hanya dapat terjadi jika komunikator dan komunikan memiliki persamaan dalam pengertian, sikap dan bahasa. Sebuah komunikasi dikatakan efektif apabila: 1). Pesan dapat diterima dan dimengerti serta dipahami sebagaimana yang dimaksud oleh pengirimnya. 2). Pesan yang disampaikan oleh pengirim dapat disetujui oleh penerima dan ditindaklanjut dengan perbuatan yang diminati oleh pengirim. 3). Tidak ada hambatan yang berarti untuk melakukan apa yang seharusnya dilakukan untuk menindaklanjuti pesan yang dikirim.

Komunikasi yang efektif terjadi bila makna yang dimaksudkan oleh pengirim berita dan makna yang ditangkap oleh penerima berita itu sama dan satu (Burhanuddin, 2014). Penelitian Rakhmat (2008) menyebutkan, komunikasi 
yang efektif ditandai dengan adanya pengertian, dapat menimbulkan kesenangan, mempengaruhi sikap, meningkatkan hubungan sosial yang baik, dan pada akhirnya menimbulkan suatu tindakan.

Komunikasi yang efektif adalah komunikasi yang terjadi apabila suatu pesan yang dikirimkan komunikator kepada penerima pesan (komunikan) dapat diterima dengan baik atau sama dengan pesan yang dimaksudkan oleh pengirim pesan, sehingga tidak terjadi salah persepsi. Pada saat menyampaikan pesan, pengirim perlu memastikan apakah pesan yang disampaikan telah diterima dengan baik oleh penerima pesan. Sementara penerima pesan perlu berkonsentrasi agar pesan dapat diterima dengan baik dan memberikan umpan balik (feedback) kepada pengirim. Umpan balik menjadi penting sebagai proses klarifikasi untuk memastikan tidak terjadi salah interpretasi terhadap pesan yang disampaikan.

Komunikasi sebagai suatu proses mempunyai faktor-faktor yang mempengaruhi komunikasi sehingga proses komunikasi dapat berjalan lancar. Burhanuddin (2014) mengatakan kelancaran dalam berkomunikasi dipengaruhi beberapa faktor, antara lain: 1). Faktor Pengetahuan. Semakin luas pengetahuan yang dimiliki seseorang, semakin banyak perbendaharaan kata yang dimiliki sehingga mempermudah berkomunikasi dengan lancar. 2). Faktor Pengalaman. Semakin banyak pengalaman yang dimiliki seseorang menyebabkan terbiasa untuk menghadapi sesuatu. Orang yang sering atau terbiasa menghadapi massa, sering berbicara di muka umum, tentu akan lancar berbicara dalam berbagai keadaan. 3). Faktor Intelegensi. Orang yang intelegensinya rendah biasanya kurang lancar dalam berbicara karena kurang memiliki perbendaharaan kata dan bahasa yang baik. Bahkan cara berbicaranya terputus-putus, antara kata yang satu dengan yang lain tidak ada relevansinya. 4). Faktor Kepribadian. Orang yang memiliki sifat pemalu dan kurang bergaul, biasanya kurang lancar berbicara dibandingkan orang yang pandai bergaul. 5). Faktor Biologis. Disebabkan oleh gangguan organ-organ berbicara sehingga menimbulkan gangguan dalam komunikasi.

\section{Komunikasi Efektif dalam Proses Pembelajaran}

Dalam proses pembelajaran, komunikasi dikatakan efektif apabila materi pelajaran yang disampaikan oleh komunikator (guru/dosen) dapat diterima, bisa dicerna dan dipahami dengan baik serta adanya feedback dari pihak komunikan (peserta didik). Agar komunikasi dalam proses pembelajaran bisa efektif maka tenaga pengajar harus memiliki ilmu dan keterampilan berkomunikasi yang baik, sehingga transformasi materi pendidikan berupa ilmu pengetahuan dan teknologi dari tenaga pendidik kepada peserta didik dapat efektif dan berhasil guna.

Pernyataan Burhanuddin (2014) bahwa proses belajar hanya efektif jika ada relasi dan komunikasi yang bermutu antara pendidik dan peserta didik dan peserta didik dengan peserta didik. Menurut Majid (2013) komunikasi dikatakan efektif dalam pembelajaran apabila terdapat aliran informasi dua arah antara pendidik dengan peserta didik dan informasi tersebut sama-sama direspon sesuai dengan harapan kedua pelaku komunikasi tersebut.

Komunikasi efektif dalam pembelajaran merupakan proses transformasi pesan berupa ilmu pengetahuan dan teknologi dari pendidik kepada peserta didik, dimana peserta didik mampu memahami maksud pesan sesuai dengan tujuan yang 
telah ditentukan, sehingga menambah wawasan ilmu pengetahuan dan teknologi serta menimbulkan perubahan tingkah laku menjadi lebih baik (Sutirman, 2006).

Proses belajar dan mengajar yang terjadi di kelas merupakan proses komunikasi antara guru dan peserta didik. Komunikasi yang lancar mempunyai andil yang cukup besar dalam upaya peningkatan kualitas pembelajaran yang dilaksanakan oleh guru. Sebagai sebuah proses transfer pengetahuan (transfer of knowledge), proses pembelajaran pada kenyataannya tidak hanya tergantung pada penguasaan materi pembelajaran oleh sang guru. Tetapi hal sesungguhnya yang sangat berperan adalah bagaimana komunikasi pendidikan tersebut dijalankan, bagaimana proses transfer pengetahuan dan keterampilan dapat dilaksanakan sesuai dengan tujuan pembelajarannya. Oleh karena itulah, maka kita perlu menyadari bahwa komunikasi atau bagaimana seorang guru mengomunikasikan materi pembelajaran kepada peserta didik menjadi salah satu kondisi yang sangat mendukung keberhasilan proses pembelajaran. Semakin baik proses komunikasi, maka semakin baik peserta didik menerima penyampaian materi tersebut dan selanjutnya pemahaman peserta didik akan meningkat (Simanjuntak, 2019).

Dalam kegiatan belajar mengajar, komunikasi antar pribadi merupakan suatu keharusan, agar terjadi hubungan yang harmonis antara pengajar dengan peserta belajar. Keefektifan komunikasi dalam kegiatan belajar mengajar ini sangat tergantung dari kedua belah pihak. Akan tetapi karena pengajar yang memegang kendali kelas, maka tanggung jawab terjadinya komunikasi dalam kelas yang sehat dan efektif terletak pada tangan pengajar (Burhanuddin, 2014).

Kualitas pendidikan yang diharapkan sangat bergantung pada kemampuan tenaga pendidik dalam melakukan komunikasi kepada peserta didik (siswa/mahasiswanya) saat proses belajar mengajar berlangsung. Komunikasi yang efektif akan mempengaruhi pada efektivitas transfer ilmu pengetahuan kepada peserta didik.

Dalam mewujudkan komunikasi pendidikan yang efektif dalam pembelajaran, guru dituntut untuk berperan dan bertanggung jawab sehingga pengajar dituntut memiliki kemampuan berkomunikasi yang baik agar menghasilkan proses pembelajaran yang efektif. Pendidik perlu menyadari akan hal ini, yaitu bahwa di dalam melaksanakan kegiatan belajar dan pembelajaran, sebenarnya dia sedang melaksanakan kegiatan komunikasi. Oleh karena itu, guru perlu selalu memilih dan menggunakan kata-kata yang sesuai dengan pengalaman murid-muridnya, agar dapat dimengerti dengan baik oleh mereka, sehingga pesan pembelajaran yang disampaikan dapat diterima dengan baik. Dalam pendidikan, khususnya pembelajaran tidak terlepas dari komunikasi yang digunakan untuk menyampaikan pesan. Untuk menciptakan proses komunikasi yang efektif, pendidik harus memahami konsep dasar komunikasi pendidikan, antara lain mengenai proses komunikasi pendidikan, teknik berkomunikasi secara efektif, bentuk komunikasi, prinsip komunikasi, komunikasi lisan dan tertulis, metode yang tepat dalam komunikasi pendidikan, strategi untuk meningkatkan efektivitas komunikasi dalam pendidikan, serta hambatan yang seringkali muncul dalam komunikasi pendidikan yang berasal dari peserta didik maupun pendidik itu sendiri (Burhanuddin, 2014).

Agar proses komunikasi pembelajaran berjalan efektif, tenaga pendidik perlu memahami karakteristik peserta didik, seperti: jalan pikirannya, hobinya, keadaannya, suasana hatinya, atau budayanya. Dalam berkomunikasi, tenaga 
pendidik harus bisa membangun kedekatan dan keakraban dengan murid atau mahasiswa. Kedekatan akan menghilangkan "penyekat" dan membuat komunikasi menjadi lancar dan mengalir dengan baik.

Sadiman (2011) mengatakan pembelajaran pada hakikatnya adalah proses komunikasi dalam pendidikan, yaitu proses penyampaian pesan dari sumber pesan ke penerima pesan melalui saluran atau media tertentu. Burhanuddin (2014) mengatakan komunikasi yang efektif dalam proses pembelajaran harus menjadi perhatian bagi para tenaga pendidik. Setidaknya ada lima aspek yang perlu dipahami dalam membangun komunikasi yang efektif, yaitu: a). Kejelasan: bahwa dalam komunikasi harus menggunakan bahasa dan mengemas informasi secara jelas, sehingga mudah diterima dan dipahami oleh komunikan. b). ketepatan: ketepatan atau akurasi, ini menyangkut penggunaan bahasa yang benar dan kebenaran informasi yang disampaikan. c). Konteks: konteks, maksudnya adalah bahwa bahasa dan informasi yang disampaikan harus sesuai dengan keadaan dan lingkungan dimana komunikasi itu terjadi. d). Alur: bahasa dan informasi yang akan disajikan harus disusun dengan alur atau sistematika yang jelas, sehingga pihak yang menerima informasi cepat tanggap. e). Budaya: dalam berkomunikasi harus menyesuaikan dengan budaya orang yang diajak berkomunikasi, baik dalam penggunaan bahasa verbal maupun nonverbal, agar tidak menimbulkan kesalahan persepsi.

Seorang pendidik yang efektif, tidak hanya efektif dalam kegiatan belajar mengajar di kelas saja (transfer of knowledge), tetapi lebih-lebih dalam relasi pribadinya dan "modeling"nya (transfer of attitude and values), baik kepada peserta didik maupun kepada seluruh anggota komunitas sekolah. Pendidikan yang humanis menekankan bahwa pendidikan pertama-tama dan yang utama adalah bagaimana menjalin komunikasi dan relasi personal antara pribadi-pribadi dan antar pribadi dan kelompok di dalam komunitas sekolah. Komunikasi dan relasi yang efektif sangat diperlukan dalam model pendidikan yang berpusat pada siswa, sebab hanya dalam suasana relasi dan komunikasi yang efektif, peserta didik akan dapat mengeksplorasi dirinya, mengembangkan dirinya dan kemudian memfungsikan dirinya di dalam masyarakat secara optimal (Riyanto, 2007).

Dalam komunikasi yang efektif, menurut Wisman (2017) terdapat lima hal yang perlu diperhatikan: 1). Respect, jika kita harus mengkritik atau memarahi seseorang, lakukan dengan penuh respek terhadap harga diri dan kebanggaan seseorang. Sebuah penghargaan yang tulus kepada siswa, membuat siswa dapat membedakan antara perlakuan yang tulus dan tidak tulus. Berikan penghargaan maka Anda sebagai seorang pendidik akan dihargai oleh siswa. Berikan penghargaan maka proses belajar mengajar menjadi sebuah proses yang menyenangkan bagi semua pihak. 2). Emphaty, perlu saling memahami dan mengerti keberadaan, perilaku, dan keinginan dari siswa. Jadi sebelum kita membangun komunikasi atau mengirimkan pesan, kita perlu mengerti dan memahami dengan empati calon penerima pesan kita. Sehingga nantinya pesan kita akan dapat tersampaikan tanpa ada halangan psikologi atau penolakan dari penerima. 3). Audible, dapat didengarkan atau dimengerti dengan baik, berarti pesan yang kita sampaikan bisa diterima dengan baik oleh penerima pesan. 4). Clarity, perlu mengembangkan sikap terbuka (tidak ada yang ditutupi atau disembunyikan), sehingga dapat menimbulkan rasa percaya (trust) dari penerima pesan. Karena tanpa keterbukaan akan timbul sikap saling curiga dan pada 
gilirannya akan menurunkan semangat dan antusiasme siswa dalam proses belajar-mengajar. 5). Humble, dengan menghargai orang lain, mau mendengar, menerima kritik, tidak sombong, dan tidak memandang rendah orang lain.

\section{Hambatan dalam Komunikasi Pendidikan}

Menurut Burhanuddin (2014) dalam proses pembelajaran, ada beberapa faktor yang menjadi hambatan proses komunikasi atau dikenal dengan istilah barriers atau noises. Faktor hambatan tersebut adalah:

Faktor Internal hambatan yang berasal dari dalam diri penerima pesan atau pembelajar itu sendiri, berupa: 1). Hambatan psikologis: hambatan ini meliputi minat, sikap, pendapat, kepercayaan, intelegensi, dan pengetahuan. Pembelajar yang senang terhadap mata pelajaran, topik, serta pengajarnya tentu lain belajarnya dibandingkan dengan pembelajar yang benci atau tidak menyukai semua itu. 2). Hambatan fisik: hambatan ini meliputi kelelahan, sakit, keterbatasan daya indera, dan cacat tubuh.Seorang pengajar perlu untuk tidak memaksakan pesan yang disampaikan harus diterima dengan cepat oleh pembelajar. Guru perlu melihat kondisi di kelas tentang hal-hal yang dapat menghambat proses penerimaan pesan.

Faktor Eksternal merupakan hambatan yang berasal dari pembelajar, seperti: 1). Hambatan budaya: hambatan ini meliputi membedakan adat istiadat, norma-norma sosial, kepercayaan, dan nilai-nilai panutan. Perbedaan adat-istiadat, norma sosial dan kepercayaan kadang-kadang dapat menjadi sumber salah paham. 2). Hambatan lingkungan: merupakan hambatan yang ditimbulkan oleh situasi dan kondisi keadaan sekitar. Proses pembelajaran ditempat yang tenang, sejuk, dan nyaman, tentu akan berbeda hasilnya jika dibandingkan proses yang dilakukan di kelas yang bising, panas dan berjubel.

Menurut Ron Ludlow dan Fergus Pantonseperti dikutip Wisman (2017), hambatan-hambatan yang menyebabkan komunikasi tidak efektif yaitu: 1). Status Effect. Adanya perbedaan pengaruh status sosial yang dimiliki setiap manusia. 2). Semantic Problems. Faktor semantik menyangkut bahasa yang dipergunakan komunikator sebagai alat untuk menyalurkan pikiran dan perasaannya kepada komunikan. 3). Perceptual Distortion. Cara pandang yang sempit pada diri sendiri dan perbedaan cara berpikir serta cara mengerti yang sempit terhadap orang lain. 4). Cultural Differences. Perbedaan kebudayaan, agama, dan lingkungan sosial. 5). Physical Distractions. Gangguan lingkungan fisik terhadap proses berlangsungnya komunikasi. 6). Poor Choice of Communication Channels. Media yang dipergunakan dalam melancarkan komunikasi. 7). No Feed Back. Tidak ada respon dan tanggapan dari receiver.

\section{SIMPULAN}

Simpulan dari tulisan ini adalah: Pertama, tidak dapat dipungkiri bahwa komunikasi menjadi sesuatu yang urgen dalam dunia pendidikan. Komunikasi dalam pendidikan merupakan komunikasi yang terjadi di dalam dunia pendidikan.Keberhasilan pendidikan banyak ditentukan oleh kemampuan dan keterampilan tenaga pendidik dalam berkomunikasi yang efektif kepada peserta didiknya. Komunikasi yang efektif mempunyai andil cukup besar dalam peningkatan kualitas dan keberhasilan proses pembelajaran. Dengan komunikasi yang efektif, maka transfer ilmu dan nilai bisa berjalan efektif pula, tetapi jika 
komunikasi tidak efektif, maka transfer ilmu dan nilai pun tidak akan optimal. Kedua, tenaga pendidik harus menyadari bahwa dalam melaksanakan kegiatan proses pembelajaran sebenarnya dia sedang melaksanakan kegiatan komunikasi. Untuk itu, tenaga pendidik sudah saatnya membekali diri dengan mempelajari "ilmu komunikasi", komponen, fungsi dan tujuan komunikasi, komunikasi efektif, komunikasi antar budaya, dan konsep dasar komunikasi pendidikan.

\section{DAFTAR PUSTAKA}

Adhim, M. F. (2005). Kado Pernikahan untuk Istriku. Yogyakarta: Mitra Pustaka.

Afid, B. (2014). Konsep Dasar Komunikasi Pendidikan. Diakses: https://afidburhanuddin.wordpress.com/2014/01/22/konsep-dasarkomunikasi-pendidikan-2/. [20/09/2019].

Effendy, O, J. (2000). Dinamika Komunikasi. Bandung: Remaja Rosdakarya.

Effendy, O, J. (2004). Ilmu Komunikasi: Teori dan Praktek. Bandung: Remaja Rosdakarya.

Hasan, E. (2005). Komunikasi Pemerintahan. Bandung: Refika Aditama.

Heryanto, N. (2008). Pentingnya Landasan Filsafat Ilmu Pendidikan Bagi Pendidikan (Suatu Tinjauan Filsafat Sains). Melalui: http://tumoutou.net/3_sem1_012/nunu_h.htm. [22/01/2008].

Larson, Mc. C. \& K. (2016). Unsru-unsur Komunikasi Efektif. Melalui: http://ciputrauceo.net/blog/2016/2/18/unsur-unsur-komunikasi-efektif. [15/10/2019].

Jalaludin, R. (2008). Psikologi Komunikasi. Edisi Revisi. Bandung: Remaja Rosdakarya.

Riyanto, T. (2007). Pendidikan yang Humanis. Melalui: http://www. bruderfic.or.id/h-60/pendidikan-yang-humanis. html. [26/07/2007].

Rudy, T. M. (2005). Komunikasi dan Hubungan Masyarakat Internasional. Bandung: Refika Aditama.

Saefuddin, U. (2019). Hakikat Pendidikan. Melalui: http://guraru.org/guruberbagi/ hakikat-pendidikan/ [21/09/2019].

Sanaky, H. A. H. (2011). Media Pembelajaran: Buku Pegangan Wajib Guru dan Dosen. Yogyakarta: Kaukaba Dipantara.

Simanjuntak, W. (2019). Interaksi Komunikasi dalam Pembelajaran. Melalui: https://www.kompasiana.com/wantisimanjuntak/5510230581331 1b62cbc69ef/interaksi-komunikasi-dalam-pembelajaran. [21/09/2019].

Sumantri, M. S. (2019). Hakikat Manusia dan Pendidikan. Modul 1. Melalui: http://repository.ut.ac.id/4028/1/MKDK4001-M1.pdf [21/09/2019].

Suprapto, H. A. (2017). Pengaruh Komunikasi Efektif untuk Meningkatkan Hasil Belajar Mahasiswa. Khazanah Pendidikan, Jurnal Ilmiah Kependidikan, 11(1). DOI: 10.30595/jkp.v11i1.2308

Sutirman, S. (2006). Komunikasi Efektif dalam Pembelajaran. Jurnal Efisiensi 2(6). DOI: https://doi.org/10.21831/efisiensi.v6i2.3857

Wisman, Y. (2017). Komunikasi Efektif dalam Dunia Pendidikan. Jurnal Nomosleca, Universitas Palangka Raya Kalimantan Tengah. 3(2).

DOI : http://doi.org/10.26905/nomosleca.v3i2.2039 